\title{
POTENSI MINYAK ATSIRI DALAM MENGHAMBAT PERTUMBUHAN ISOLAT BAKTERI YANG DITEMUKAN DI CANDI BOROBUDUR
}

\author{
Absari Hanifah \\ Program Studi Biologi Universitas Negeri Yogyakarta \\ absarihanifah@gmail.com
}

\begin{abstract}
Abstrak : Penelitian ini bertujuan untuk mengetahui isolat bakteri dari Candi Borobudur dan penghambatan pertumbuhan bakteri dengan minyak atsiri. Tempat penelitian yaitu di Laboraturium Mikrobiologi Balai Konservasi Borobudur, menggunakan Rancangan Acak Lengkap (RAL), terdapat 16 sampel bakteri yang diambil dari relief Candi Borobudur pada lantai 2. Masing-masing sampel diambil dari 4 sisi bidang relief batu candi. Penelitian terdiri dari tahap persiapan, pengambilan sampel, karakterisasi bakteri, uji mikroskopi, pemilihan bakteri uji, dan uji minyak atsiri. Minyak atsiri yang digunakan adalah temulawak, nilam, dan daun cengkeh dengan distilasi uap air. Konsentrasi minyak atsiri yang digunakan yaitu 10\%. 20\%, dan 30\% dengan metode pengenceran menggunakan alkohol 90\% sebagai pelarut. Bakteri yang digunakan sebagai isolat uji dengan minyak atsiri adalah isolat bakteri yang paling banyak ditemukan di batu lapuk dan tidak ditemukan pada batu relief kompak. Hasil penelitian menunjukkan minyak atsiri yang berpotensi untuk menghambat pertumbuhan bakteri adalah minyak atsiri nilam dengan konsentrasi 30\% dengan rata-rata penghambatan 1,075 cm.
\end{abstract}

Kata Kunci : Bakteri, Minyak Atsiri, Borobudur

\begin{abstract}
The aim of this research was to know the inhibition of bacterial growth isolated from Borobudur Temple with essential oils. The research was done in Microbiology Laboratory of Borobudur Conservation Office, used a complete randomized design study technique. Samples taken from the reliefs of Borobudur Temple were 16 samples found on the 2nd floor. Each sample was drawn from 4 sides of the temple stone relief fields. The study consisted of preparation, sampling, bacterial characterization, microscopy test, selection of test bacterial, and antibacterial test using essential oils. Essential oils used were temulawak, patchouli, and clove leaves from steam distillation method. The concentration of essential oil used is 10\%. 20\%, and 30\% by dilution method using $90 \%$ alcohol as a solvent. The bacterial used as a test isolate with essential oils were the most common bacterial found in decayed stones and were not found in compact stone reliefs. The research result showed essential oil wich have the potential to inhibit the growth of bacteria was a type of patchouli with a concentration of $30 \%$ with an average of inhibition $1,075 \mathrm{~cm}$.
\end{abstract}

Keywords : Bacteria, Essential Oils, Borobudur.

\section{PENDAHULUAN}

WarisanDuniakompleks CandiBorobudurberdiri sejak abad ke-8 atau ke-9 Masehi terletak di Kabupaten Magelang, Jawa Tengah. Dinding dan pembatasnya dihiasi relief indah seluas $2500 \mathrm{~m} 2$. Bahkan, ada pula yang memperkirakan peninggalan Dinasti Syailendra ini dibangun secara bertahap dalam kurun waktu yang cukup lama dari tahun 780 hingga 833 M (Tanudirjo, 2007: 1). Umur batuan candi yang sudah lebih dari seribu tahun ini telah masuk dalam daftar Warisan Dunia yang diakui oleh
UNESCO. Batuan Candi Borobudur yang tua berisiko mengalami berbagai kerusakan dan pelapukan sehingga harus dilakukan berbagai penanganan dan konservasi untuk menjaga kelestaraian Candi Borobudur.

Balai Konservasi Borobudur (BKB) merupakan Unit Pelayanan Teknis di bawah Kementerian Pendiidkan dan Kebudayaan yang berwenang dalam pengelolaan dan konservasi Candi Borobudur dengan melaksanakan berbagai kegiatan untuk mencegah kerusakan batu candi akibat tumbuhnya bakteri, lumut, dan mikroorganisme 
perusak batu candi yang lain. Namun selama ini proses konservasi masih menggunakan bahan kimia berbahaya seperti 5-bromo-3-sec-butyl-6-methyluracil (Hyvar-X), xylophene, aldrin, malathion, parathion, DDT (Dichloro Diphenyl Trichloroethane) dan CCA (Chromated Copper Arsenat). Oleh karena itu dilakukan penelitian mengenai bahan yang ramah lingkungan sebagai pengganti bahan kimia untuk koservasi candi yaitu dengan minyak atsiri, yang diambil dari tanaman sereh wangi, cengkeh, pala, jahe karena mengandung zatzat aktif seperti sitronelal, sitronelol, geraniol, eugenol, cineol, dan camphene yang dapat membasmi, membunuh, dan mengusir serangga, jamur, dan bakteri. Penggunaan minyak atsiri sebagai bahan konservasi aman terhadap lingkungan, manusia, dan mampu mencegah kerusakan (Riyanto, 2014: 4).

Selama ini, kerusakan yang ada di Candi Borobudur adalah pelapukan batuan yang disebabkan oleh bahan-bahan organik. Pelapukan organik yaitu proses penghancuran benda termasuk benda cagar budaya yang diakibatkan oleh aktivitas makhuk hidup, baik hewan maupun tumbuhan. Secara umum beberapa mikrorganisme penyebab pelapukan yaitu bakteri dan jamur. Mikroorganisme penyebab kerusakan yang ditemukan di Candi Borobudur diantaranya adalah jamur, alga, dan bakteri. Bakteri merupakan salah satu jasad renik yang berbentuk seperti batang, peluru, dan sekrup yang merupakan makhluk hidup yang kasat mata. Untuk dapat mengamati dan mengenal bakteri secara seksama diperlukan bantuan mikroskop. Berdasarkan hasil penelitian di Candi Borobudur, bakteri dan jamur dapat mempercepat proses pelapukan. Batuan Candi Borobudur yang kaya mineral penting merupakan tempat yang tepat bagi tumbuhnya organisme saprofit. Mineral-mineral batuan tersebut bereaksi dengan bahanbahan organik dan makhluk hidup saprofit sehingga terjadilah pelapukan.

Bakteri yang tumbuh di Candi Borobudur diantaranya adalah bakteri fotoautotrof yang dapat mensintesis senyawa organik dengan menggunakan energi cahaya matahari tidak langsung. Bakteri tersebut menghasilkan berbagai senyawa asam yang dapat bereaksi dengan oksida batuan. Contoh bakteri yang ada pada batuan Candi Borobudur adalah Amonifiri sp, Acetobacter sp dan Fictobacter fixing (Riyanto, 2014:
5). Oleh karena itu, pencegahan dari pertumbuhan mikroorganisme pelapuk batuan perlu dilakukan. Salah satunya adalah dengan memanfaatkan bahan alam minyak atsiri dalam menghambat pertumbuhannya. Dampak adanya bakteri pada batuan candi akan mempercepat proses pelapukan dan menghilangkan tekstur asli batu. Berdasarkan penelitian sebelumnya belum pernah dilakukan penelitian mengenai minyak atsiri potensial sebagai anti bakteri pada batu candi. Oleh karena itu dalam penelitian ini penulis bermaksud untuk melakukan penelitian mengenai potensi minyak atsiri yang efektif dalam menghambat pertumbuhan bakteri batu di Candi Borobudur.

\section{METODE PENELITIAN}

\section{Jenis Penelitian}

Penelitian ini merupakan penelitian eksperimen.

\section{Waktu dan Tempat Penelitian}

Penelitian ini dilaksanakan di Laboratorium Mikrobiologi Balai Konservasi Borobudur selama 1 bulan mulai tanggal 9 Oktober - 9 November 2017.

\section{Populasi dan Sampel}

Populasi dari penelitian meliputi semua isolat bakteri yang diambil di lantai 2 Candi Borobudur. Sampel penelitian yaitu 1 isolat bakteri pada relief batu lapuk Candi Borobudur.

\section{Prosedur Penelitian}

\section{Pengambilan sampel}

Sampel bakteri diambil pada relief candi dipilih pada daerah relief yang memiliki struktur batu kompak dan struktur batu lapuk. Pengambilan sampel dilakukan di lantai 2 Candi Borobudur pada tiap sisi. Yaitu sisi Barat blok F, sisi Utara blok C, sisi Selatan blok C, dan sisi Timur blok C batu kompak dan sisi Timur blok D batu lapuk. Teknik pengambilan sampel bakteri dilakukan dengan cotton bud yang telah disterilkan sebelumnya. Kemudian metode swept yang dilakukan diberikan lampu Bunsen dibawahnya untuk mengurangi tingkat kontaminasi. Cotton bud diusapkan pada bagian yang diduga terdapat bakteri pada batu relief yang lapuk dan kompak. Pengolesan dilakukan dengan maksimal luasan $100 \mathrm{~cm} 2$ pada luasan daerah relief. selama kurang lebih 5 detik kemudian menyimpan sampel pada plastik untuk menghindari kontaminan. 


\section{Sterilisasi Alat}

Menyiapkan semua alat dan media yang akan digunakan untuk menanam sampel bakteri dan pengujian kemudian pada medium padat NA. Diawali dengan mencuci dan membersihkan semua alat dengan menyemprotkan dengan alkohol $70 \%$ dan mengelap dengan tissue pada alat, kemudian membungkus dengan kertas penutup dan memasukkan pada autoklaf dengan suhu $121^{\circ} \mathrm{C}$ selama 15 menit. Menurut Suswati dkk (2011:26) semua alat yang akan dipakai dalam penelitian dicuci bersih sebelumnya. Kemudian dikeringkan, dan disterilkan dengan autoklaf. Sedangkan bahan media disterilkan dalam autoklaf selama 20 menit dengan suhu 121oC. Tujuan sterilisasi alat adalah untuk menghindarkan dari kontaminasi.

\section{Pembuatan Medium untuk Menumbuhkan}

\section{Bakteri}

Menyiapkan dan menimbang media Agar NA 9,75 gram pada timbangan digital. Menuangkan pada Erlenmeyer yang diberikan akuades sebanyak $250 \mathrm{ml}$. Memanaskan medium di atas kompor listrik dengan suhu $100^{\circ} \mathrm{C}$ sambil diaduk sampai merata pelarut dengan medium. Menunggu kurang lebih 10 menit kemudian diangkat. Setelah terlihat homogen pada medium maka segera dimasukkan ke autoklaf untuk melakukan sterilisasi medium yang akan digunakan. Suhu dan waktu autoklaf di atur pada suhu $121^{\circ} \mathrm{C}$ selama 15 menit. Kemudian menunggu sampai 15 menit, dan menuangkan pada cawan petri setelah medium sudah berkurang panasnya. Penuangan medium pada cawan petri membutuhkan sterilisasi yaitu dengan menuang di dekat api bunsen yang telah dinyalakan untuk menghindari dari kontaminasi. Setelah dituangkan maka ditunggu selama 10 menit untuk menunggu sampai agar mengeras dan siap digunakan untuk inokulasi bakteri.

\section{Inokulasi Bakteri}

Inokulasi bakteri dilakukan dengan cara steril yaitu mempersiapkan api bunsen. Inokulasi dilakukan di dalam LAF. Menyiapkan media agar yang telah siap dan menyiapkan sampel bakteri pada cotton bud. Metode yang dilakukan adalah dengan cara sweep, yaitu mengusapkan cotton bud dengan sampel bakteri langsung pada media dengan metode strike. Caranya adalah dengan membuka tutup cawan petri di dekat cawan agar, kemudian langsung melakukan strike cotton bud dengan cepat kemudian menutupnya kembali dan menutup dengan kertas. Kemudian dimasukkan kedalam inkubator dengan suhu $37^{\circ} \mathrm{C}$. Menunggu kurang lebih 4 hari dan melihat perkembangan dan dilakukan identifikasi jenis bakteri yang ditemukan.

\section{Karakterisasi bakteri}

Setelah diketahui bakteri telah tumbuh pada media maka dapat dilakukan karakterisasi pada bakteri yang ditemukan. Karakterisasi dibagi menjadi beberapa uji salah satunya adalah uji morfologi dan uji mikroskopi bakteri. Langkah awal yaitu dengan membuat preparat mengambil secara steril menggunakan jarum ose dan didekatkan lampu bunsen, selanjutnya diletakkan pada preparat dan menutup dengan cover glass. Kemudan dilakukan pengecatan gram kemudian pengamatan di bawah mikroskop sampai perbesaran 1000 kali. Mencatat dan mencocokkan dengan buku identifikasi yang ada.

Pengenalan bentuk mikroba (morfologi) secara mikroskopi, khususnya bakteri dapat dilakukan dengan pewarnaan terlebih dahulu agar memudahkan pengamatan. Pengecatan gram dapat dilakukan dengan 4 cara yaitu:

a. Pemberian cat warna utama (cairan Kristal violet) berwarna ungu.

b. Pengintensifan zat warna utama dengan penambahan larutan mordan.

c. Pencucian (dekolarisasi) dengan larutan alkohol asam.

d. Pemberian cat warna lawan yaitu safranin (Khairunnisa, 2016: 4-8).

\section{Subkultur bakteri}

Subkultur bakteri adalah langkah untuk memisahkan dari satu jenis bakteri dengan jenis lainya pada medium di cawan petri atau tabung reaksi. Sehingga hanya didapatkan 1 jenis bakteri yang akan diuji dengan menggunakan 3 jenis minyak atsiri.

\section{Inokulasi Bakteri pada Medium Cair (Pour Plate)}

Menginokulasi dengan medium agar NB cair bertujuan untuk mendapatkan bakteri yang dapat tumbuh menyebar pada seluruh permukaan media. Caranya adalah mengambil sampel bakteri dengan jarum ose dan langsung memasukkan pada medium agar NB cair dan mengaduknya agar tercampur. Kultur bakteri pada NB cair kemudian di shaker selama 24 jam. Kemudian ketika akan diaplikasikan untuk uji antibakteri dapat dipindahkan kultur yang telah jadi sebanyak $1 \mathrm{ml}$ dengan mikro pipet 
pada cawan petri berisi agar NA padat dan diratakan dengan drygalsky secara steril kemudian menutup kembali cawan petri dan dibiarkan dingin. Menyimpan pada inkubator dan disimpan pada suhu $27^{\circ} \mathrm{C}-30^{\circ} \mathrm{C}$. Menunggu sampai 24 hingga 48 jam kemudian diamati pertumbuhanya.

\section{Desain Penelitian Uji Minyak Atsiri pada Bakteri}

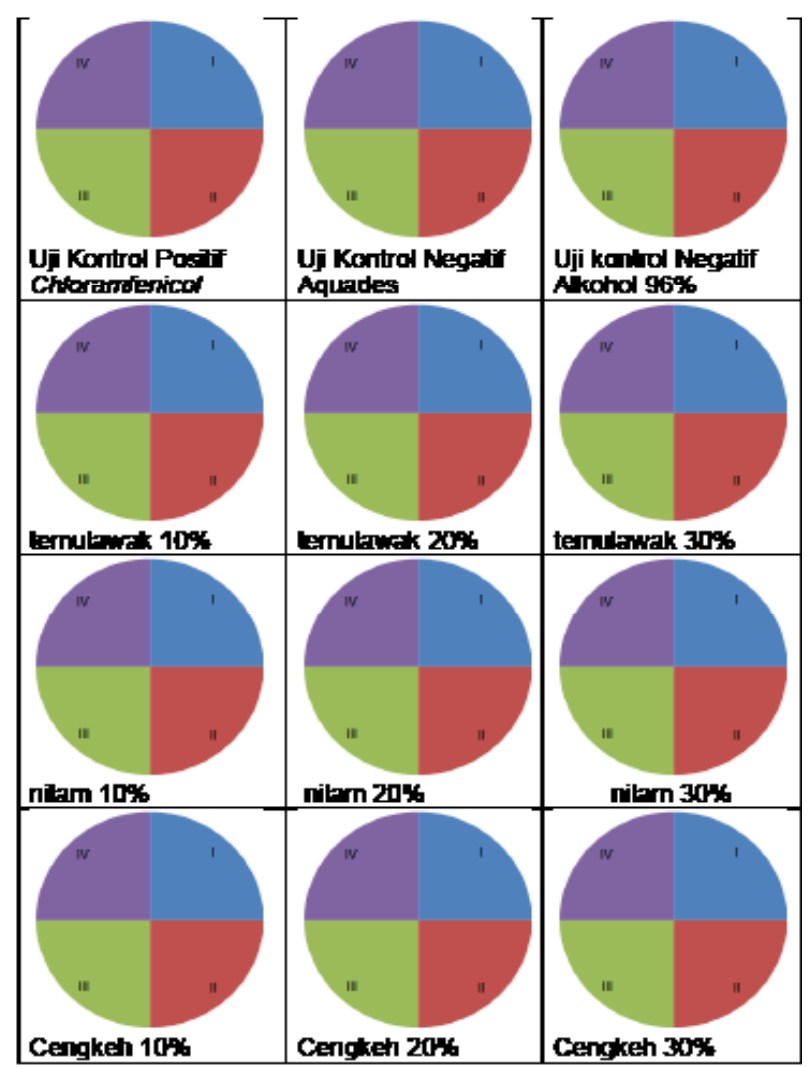

9. Menanam Kertas Cakram Steril pada Rendaman Minyak Atsiri

Merendam cakram kertas steril pada masingmasing 3 jenis minyak atsiri dengan perbedaan konsentrasi 10\%,20\%,30\%. Minyak atsiri sebelumnya dimasukkan ke dalam labu ukur yang dilarutkan pada $10 \mathrm{ml}$ alkohol 96\%. Direndam selama 15 menit. Kemudian dituang kedalam cawan petri. Selanjutnya adalah melakukan penanaman pada cawan petri yang berisi medium dengan bakteri. Diletakkan pada permukaan agar yang telah padat dengan 4 kertas cakram yang berada pada 4 kuadran yang berbeda sebagai pengulangan. Satu cawan petri dengan 4 kuadran diisi dengan kertas cakram steril yang direndam dengan 12 jenis cairan yang berbeda yaitu akuades, alkohol 96\% sebagai kontrol negatif, larutan chloramfenikol 200mg/ ml sebagai kontrol positif, dan larutan rendaman minyak atsiri nilam, cengkeh, dan temulawak dengan konsentrasi yang berbeda yaitu 10\%, 20\%, 30\%.

\section{Pengamatan Zona Penghambat Pada Medium}

Uji aktifitas minyak atsiri dilakukan mengikuti standar AATCC 147-1998 dan AATCC 100-1999. Pengamatan zona hambat dapat diketahui dengan mengamati diameter zona kertas cakram dan diameter zona bening yang telah direndam dengan minyak atsiri. Daya hambat material uji ini diketahui dengan mengukur lebar zona bening di sekitar kertas cakram (dalam millimeter), sedangkan penentuan antibakteri secara kuantitatif dilakukan dengan cara menghitung presentase reduksi biakan bakteri (Tatang Wahyudi, 2011: 56).

\section{Teknik Pengumpulan Data}

Medium yang ditumbuhi bakteri diberi perlakuan dengan minyak atsiri menggunakan paperdisk selanjutnya diukur zona penghambatan paperdisk pada medium menggunakan jangka sorong setelah 24 jam.

\section{Teknik Analisis Data}

Data dianalisis menggunakan teknik deskriptif analisis.

\section{HASIL DAN PEMBAHASAN}

\section{Hasil Karakterisasi Bakteri Isolat Candi Borobudur}

Hasil karakterisasi morfologi dari jenis bakteri yang ditemukan pada saat pengambilan sampel di area sisi Barat blok F, Timur Blok D, Selatan blok C, dan Utara blok C pada lantai 2 Candi Borobudur diantaranya ditemukan 5 jenis bakteri yang ditemukan di relief batu lapuk. Sedangkan pada relief batu kompak ditemukan 10 jenis bakteri. Sehingga jenis bakteri keseluruhan yang ditemukan adalah 15 jenis bakteri. Berdasarkan karakterisasi morfologi sampel bakteri pada batu lapuk, dihasilkan data terdapat 3 sampel yang memiliki karakteristik sama dan 2 jenis bakteri yang memiliki karakteristik berbeda. Tiga jenis bakteri tersebut adalah yang ditemukan pada lokasi barat, satu sampel pada sisi Utara sampel ke 2, dan satu sampel pada sisi selatan. Memiliki karakteristik bentuk ireguler, elevasi crateriform, margin lobate, dan kontur smooth. Sedangkan 1 jenis bakteri yang ditemukan pada sisi Utara sampel ke 1 memiliki karakteristik bentuk ireguler, elevasi umbonate, margin lobate, dan kontur contoured, dan satu sampel pada derah timur ditemukan satu jenis yang berbeda 
dengan ciri-ciri ireguler, crateriform, undulate, smooth. Berdasarkan karakterisasi morfologi pada sampel yang diambil dari relief batu kompak dihasilkan 9 jenis bakteri yang berbeda-beda karakteristiknya dan tidak terdapat jenis bakteri yang sama. Hal ini membuktikan bahwa jenis bakteri pada batu kompak lebih banyak jenis keanekaragaman bakterinya dibandingkan dengan jenis bakteri yang terdapat pada relief batu lapuk. Namun berdasarkan pengamatan pada batu lapuk ditemukan bakteri yang sama pada beberapa sampel yang diambil. Hal ini menunjukkan terdapat bakteri dominan pada relief batu yang lapuk. Sedangkan berdasarkan pengamatan pula, bakteri yang ditemukan pada relief batu lapuk tidak ada yang sama dengan bakteri yang ditemukan pada batu kompak. Oleh karena itu dapat dijadikan sebagai acuan penelitian dalam pemilihan bakteri yang akan diujikan selanjutnya menggunakan minyak atsiri. Uji penghambatan dengan minyak atsiri akan dipilih jenis bakteri dominan yang tumbuh pada batu lapuk dan tidak terdapat pada batu kompak. Sehingga dalam penelitian ini bakteri yang diujikan adalah bakteri yang ditemukan pada batu lapuk dari sampel yang diambil di sisi Barat, Utara, dan Selatan dengan kode BL, UL2, dan SL.

\section{Hasil Uji Mikroskopi Bakteri}

Berdasarkan penelitian yang dilakukan, setelah didapatkan data mengenai ciri morfologi bakteri isolat yang diambil dari relief batu Candi Borobudur, kemudian dilakukan pengamatan secara mikroskopi untuk melengkapi ketepatan data dari pengamatan secara morfologi. Hal tersebut digunakan juga untuk mengetahui karakteristik bentuk dan jenis bakteri merupakan bakteri positif atau negatif.
Tabel 1. Kenampakan Mikroskopi Bakteri Batu Lapuk

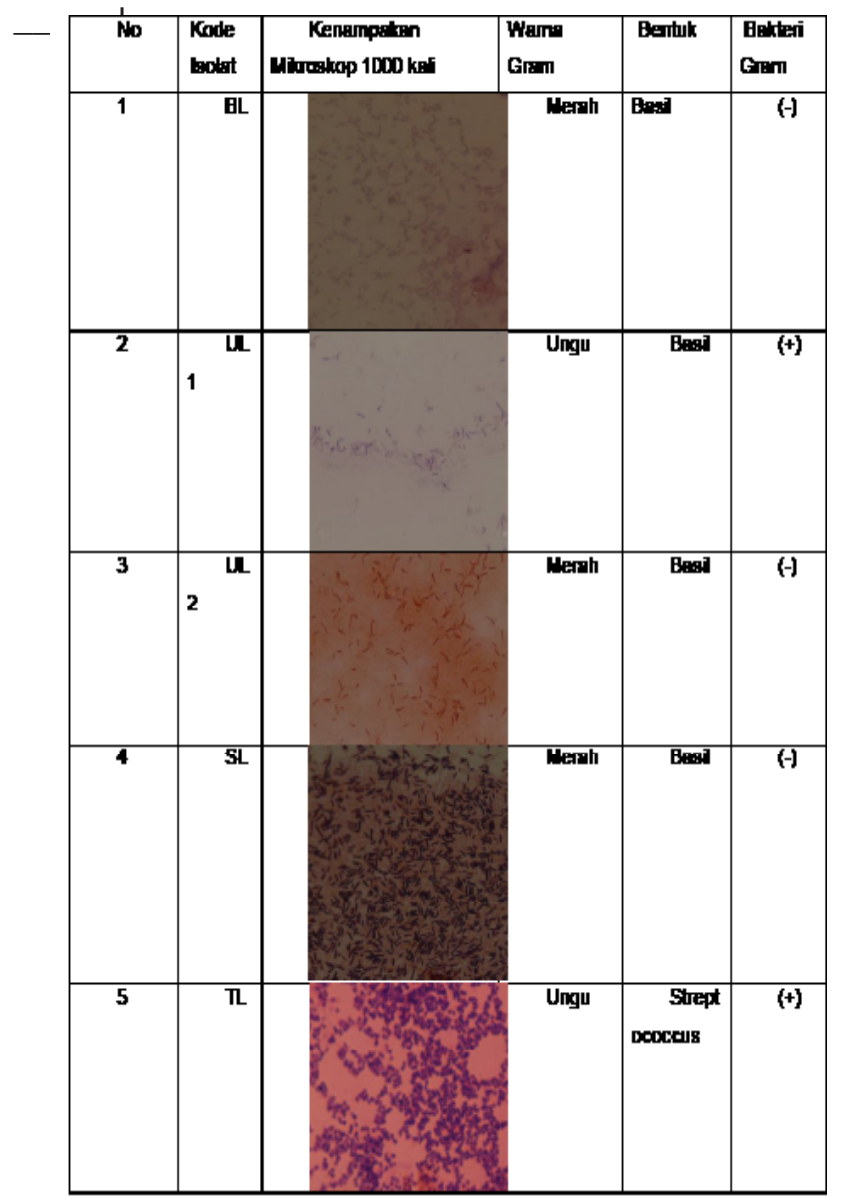

Sedangkan pengamatan mikroskopi yang dilakukan pada bakteri yang terdapat pada batu kompak dihasilkan data sebagai berikut:

Tabel 2. Kenampakan Mikroskopi Bakteri Batu Kompak

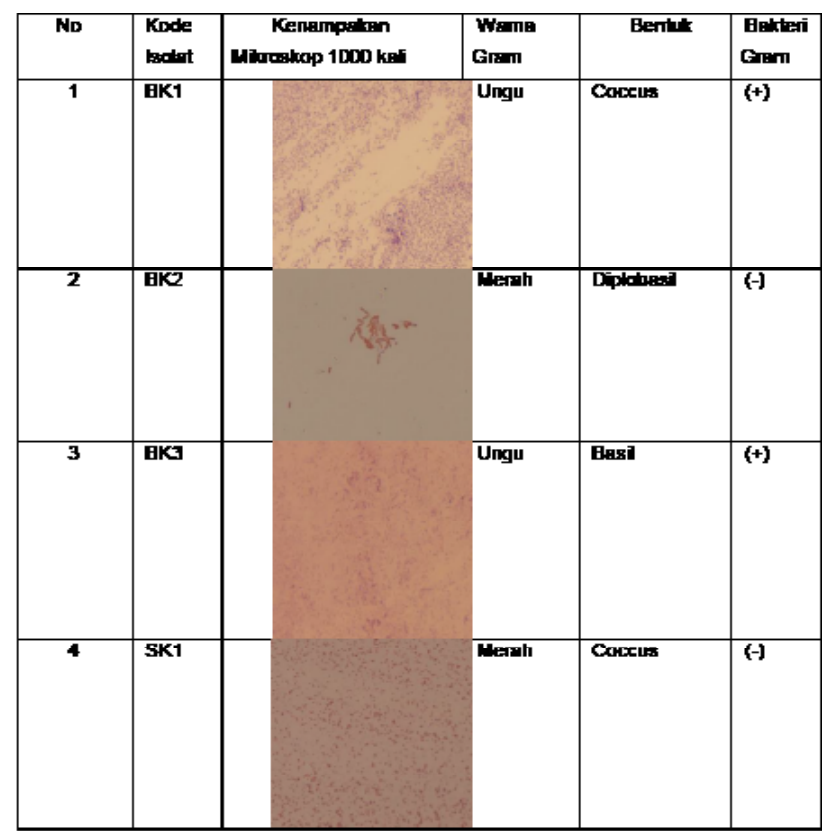




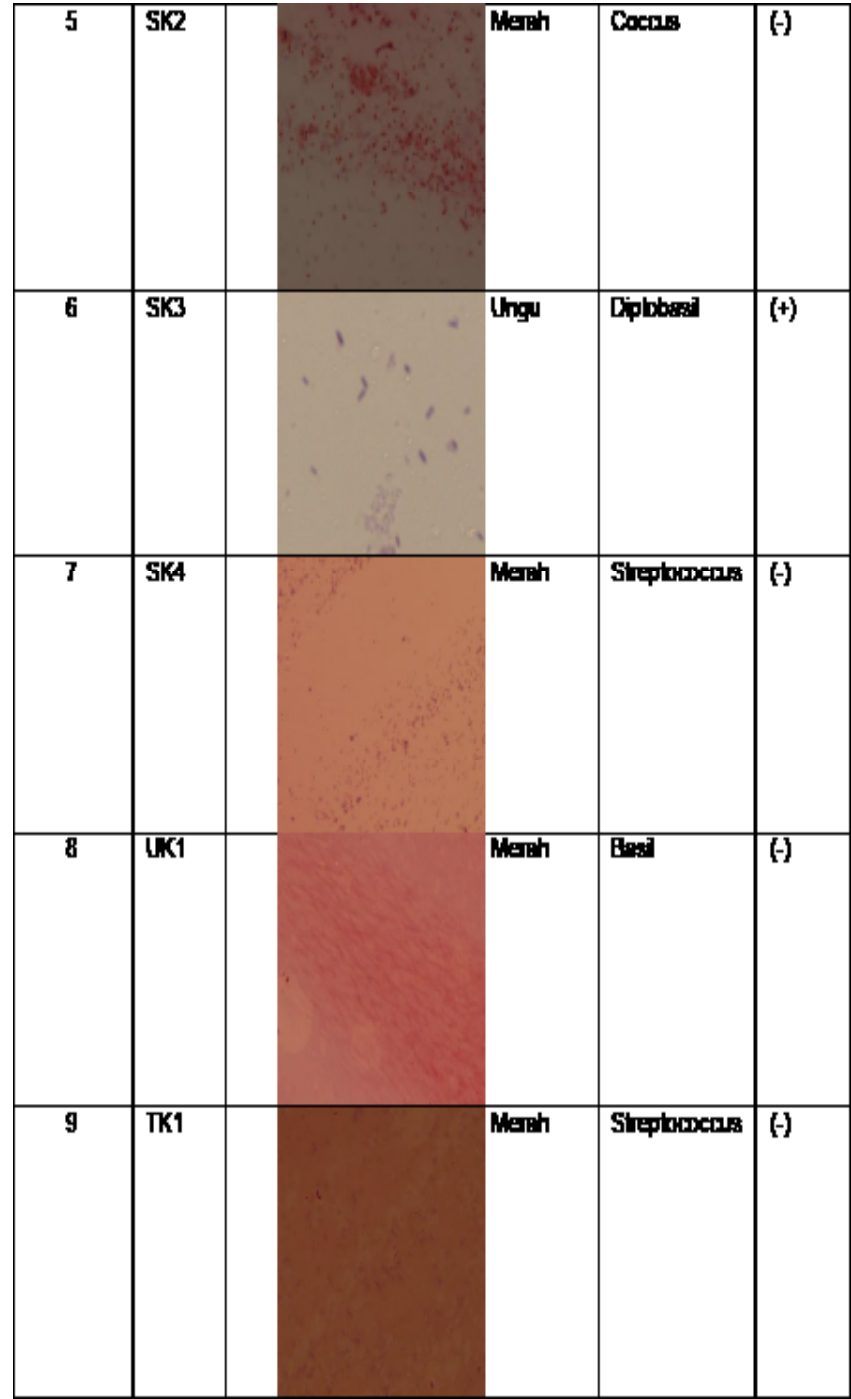

Berdasarkan teori yang dikatakan oleh Khairunnisa (2016: 8) mengatakan bahwa ciri-ciri bakteri gram negatif adalah sebagai berikut:

1. Struktur dinding sel nya tipis, sekitar $10-45 \mathrm{~cm}$, berlapis tiga atau multi layer

2. Dinding selnya mengandung lemak lebih banyak (11-12\%), peptidoglikan terdapat pada lapisan kaku, sebelah dalam dengan jumlah sedikit 10\% dari berat kering, tidak mengandung asam laktat.

3. Kurang rentan terhadap senyawa penisilin.

4. Tidak resisten terhadap gangguan fisik.

Sedangkan ciri-ciri bakteri gram positif diantaranya adalah:

1. Struktur dindingnya tebal

2. Dinding selnya mengandung lipid yang lebih normal

3. Bersifat lebih rentan terhadap penisilin.

4. Pertumbuhan dihambat secara nyata oleh zat-zat seperti ungu kristal.

5. Komposisi yang dibutuhkan lebih rumit.

\section{Lebih resisten terhadap gangguan fisik}

Berdasarkan teori yang ada dapat disimpulkan, pengamatan secara morfologi dan mikroskopi menunjukkan bahwa bakteri yang ditemukan pada batu lapuk memiliki ciri berbeda baik dari penampakan morfologi maupun mikroskopi. Oleh karena itu penetapan bakteri yang akan diuji yang diduga dapat mengakibatkan pelapukan adalah bakteri dengan kode isolat yang ditemukan pada sampel yang diambil di sisi Barat, Utara, dan Selatan dengan kode BL, UL2, dan SL. Jenis bakteri yang diuji yaitu bakteri berwarna merah, bentuk basil, dan termasuk bakteri negatif.

Hasil Pengujian Penghambatan Bakteri dengan Minyak Atsiri

Berdasarkan penelitian yang dilakukan dihasilkan data keseluruhan yang mencakup hasil perhitungan ratarata dari penghambatan potensi minyak atsiri terhadap pertumbuhan isolat bakteri yang diambil dari Candi Borobudur. Data yang dihimpun yaitu sebagai berikut :

Tabel 3. Hasil Uji Rata-Rata Penghambatan Bakteri

\begin{tabular}{|c|c|}
\hline 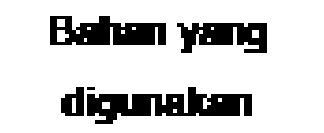 & $\begin{array}{c}\text { Rata-Rata } \\
\text { Peglumbat: l (on) }\end{array}$ \\
\hline Appodes & 口 \\
\hline Arphad SpX & ם \\
\hline Chloriferial & 1,1,175 \\
\hline Temularit 10x & 0,3375 \\
\hline Tenulenit Zurs & 0,3875 \\
\hline Tenularit 3urs & $\overline{0,1}$ \\
\hline$N=\ln 10 \times 5$ & 0,1775 \\
\hline$N^{2}: \mathrm{n} 2 \mathrm{n}$ & 0,5325 \\
\hline$N=11305$ & 1,175 \\
\hline Cengledi 1D: & 0,38 \\
\hline Cengkein 215 & 0,375 \\
\hline Cengked 30x & 0,255 \\
\hline
\end{tabular}


Berdasarkan hasil rata-rata menunjukkan bahwa kontrol positif dan kontrol negatif bekerja secara efektif, yaitu sebagai kontrol positif chloramfenikol berhasil menghambat 1,0075 cm, kemudian alkohol 96\% dan aquades tidak menghambat. Selain itu minyak atsiri potensial yang dapat menghambat bakteri terbanyak adalah minyak atsiri nilam dengan konsentrasi 30\% dengan diameter penghambatan 1,075 cm melebihi dari kontrol positifnya yaitu chloramfenikol.

Hasil rata-rata penghambatan yang berpotensi sebagai antibakteri dari tiap minyak atsiri diantaranya adalah Nilam dengan konsentrasi 30\%, Temulawak konsentrasi 20\% dengan diameter penghambatan 0,3875 cm, dan Cengkeh konsentrasi 20\% dengan diameter penghambatan $0,395 \mathrm{~cm}$.

Hasil rata-rata penghambatan yang berpotensi sebagai antibakteri dari tiap minyak atsiri disajikan pada grafik dengan hasil sebagai berikut:

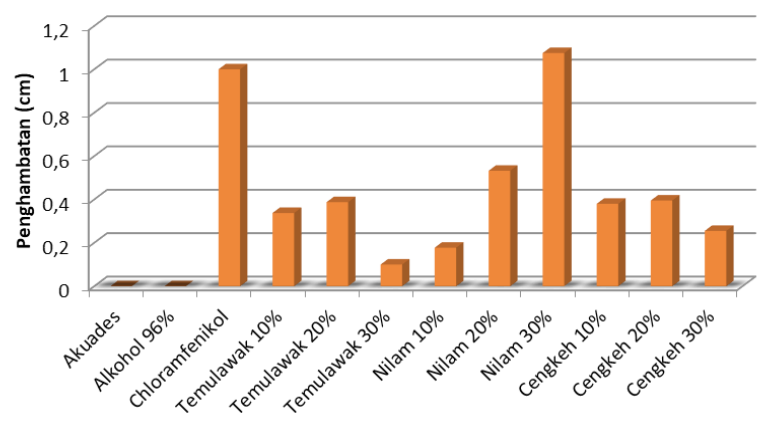

enis Senyawa Penghambat

\section{Gambar 1. Diagram Rata-Rata Penghambatan}

Pemberian Larutan Terhadap Bakteri Isolat Candi Borobudur

Diagram menunjukkan bahwa minyak atsiri paling efektif untuk menghambat pertumbuhan bakteri isolat Candi Borobudur adalah minyak atsiri Nilam konsentrasi 30\% dengan diameter penghambatan 1,075 cm yang melebihi penghambatan chloramfenikol dengan diameter penghambatan 1,0075 cm.

\section{Hasil Pengujian Penghambatan Bakteri dengan Kontrol Positif dan Negatif}

Berdasarkan pengamatan yang dilakukan pada pengujian minyak atsiri dalam menghambat pertumbuhan bakteri, telah dihasilkan data seperti pada Tabel 4:
Tabel 4. Hasil Uji Penghambatan Bakteri dengan

\section{Kontrol}

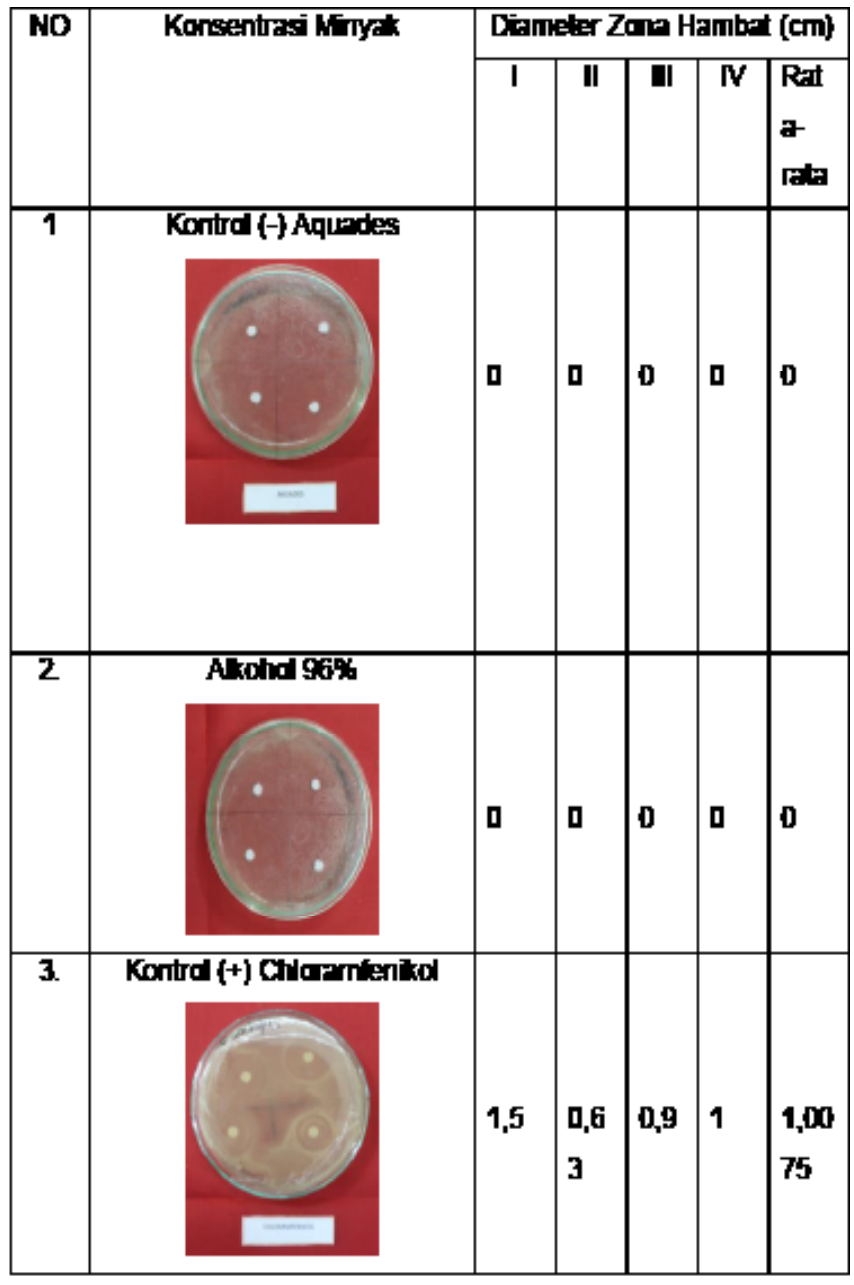

Berdasarkan hasil pengamatan, dihasilkan data bahwa sebelum dilakukan uji minyak atsiri terhadap penghambatan pertumbuhan bakteri maka dilakukan uji kontrol terlebih dahulu. Uji kontrol yang dilakukan adalah dengan menggunakan kontrol positif dan uji kontrol negatif yang disamakan perlakuan dan pengulangannya. Yaitu uji positif menggunakan cairan chloramfenikol $2000 \mathrm{mg} / \mathrm{mL}$ yang dilarutkan dengan aquades steril 10 $\mathrm{ml}$, kemudian uji kontrol negatif yaitu pengujian kertas cakram yang direndam pada aquades steril dan alkohol $96 \%$. Berdasarkan pengamatan yang dilakukan pada uji negatif menggunakan akuades dan alkohol 96\% yang digunakan sebagai pelarut minyak atsiri, tidak terdapat penghambatan sedikitpun, hal ini membuktikan bahwa pengujian negatif berhasil dilakukan dan membuktikan akuades steril tidak memiliki kemampuan dalam penghambatan bakteri. Sedangkan pengujian positif menggunakan chloramfenikol yang dikenal sebagai antibakteri membuktikan bahwa terdapat penghambatan 
yang cukup signifikan dengan pemberian chloramfenikol sebagai uji positif penghambatan bakteri uji. Pengamatan terhadap efektifitas uji positif dan negatif ini dilakukan pengamatan skala laboraturium pada saat penanaman umur 1 hari. Cara pengukuran diameter zona hambat dengan menggunakan jangka sorong sebanyak 4 kali pengulangan.

Hasil Pengujian Penghambatan Bakteri dengan Minyak Atsiri Temulawak

Hasil pengujian efektivitas minyak atsiri temulawak dengan berbagai variasi konsentrasi menggunakan metode difusi agar terhadap bakteri yang ditemukan di Candi Borobudur, telah dihasilkan data seperti pada Tabel 5:

Tabel 5. Hasil Uji Penghambatan Bakteri dengan Minyak Atsiri Temulawak

\begin{tabular}{|c|c|c|c|c|c|c|}
\hline \multirow[t]{2}{*}{ NO } & \multirow[t]{2}{*}{ Konsentrasi Minyak } & \multicolumn{5}{|c|}{ Diameter Zona Hambal (cm) } \\
\hline & & 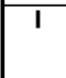 & II & III & $\mathbf{N}$ & $\begin{array}{l}\text { Reta } \\
\text { rata }\end{array}$ \\
\hline 1. & Temulant 10\% & 0,35 & 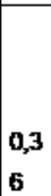 & $\begin{array}{l}0,3 \\
2\end{array}$ & $\begin{array}{l}0,3 \\
2\end{array}$ & 0,3375 \\
\hline 2. & Temultwet 20\% & 0,4 & 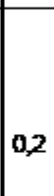 & 0,5 & $\begin{array}{l}0,4 \\
5\end{array}$ & 0,3875 \\
\hline 3. & Temultack 30\% & 0,1 & 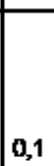 & 0,1 & 0,1 & 0,1 \\
\hline
\end{tabular}

Berdasarkan pengamatan laboratorium dengan pengukuran sebanyak 4 kali ulangan dari tiap diameter zona hambat didapatkan data seperti pada Tabel 5. Minyak atsiri yang digunakan salah satunya adalah temulawak, minyak temulawak dengan konsentrasi 20\% lebih baik karena dapat menghambat sampai 0,3875 cm. Sedangkan pada konsentrasi 10\% tidak jauh berbeda dengan rata-rata penghambatan adalah 0,3375 cm. Sedangkan pada temulawak dengan konsentrasi
30\% menghasilkan penghambatan terkecil diantaranya adalah $0,1 \mathrm{~cm}$. Hasil percobaan ini sebanding dengan hasil analisis kandungan dalam minyak atsiri temulawak terdapat senyawa kurkumin sebanyak 20,55\% yang memiliki gugus hidroksi fenolik dan gugus $\beta$-diketon yang berfungsi sebagai antibakteri.

Hasil Pengujian Penghambatan Bakteri dengan Minyak Atsiri Nilam

Hasil pengujian efektifitas minyak atsiri nilam dengan berbagai variasi konsentrasi menggunakan metode difusi agar terhadap bakteri yang ditemukan di Candi Borobudur, disajikan pada Tabel 6 di bawah ini :

Tabel 6. Hasil Uji Penghambatan Bakteri dengan Minyak Atsiri Nilam

\begin{tabular}{|c|c|c|c|c|c|c|}
\hline \multirow[b]{2}{*}{$\begin{array}{l}\mathbf{N} \\
\mathbf{0}\end{array}$} & \multirow[b]{2}{*}{ Karsentras Minyct } & \multicolumn{5}{|c|}{ Diarneter Zona Harnbut (dn) } \\
\hline & & I & II & 미 & $\mathbf{N}$ & Rata-rata \\
\hline 1. & Niam 10\% & 0,1 & 0,1 & $\begin{array}{l}0,1 \\
B\end{array}$ & $\begin{array}{l}0,3 \\
3\end{array}$ & 0,1775 \\
\hline 2. & Nam Z\% & 0,8 & $\mathbf{0 , 6}$ & $\begin{array}{l}0,3 \\
3\end{array}$ & 0,4 & . \\
\hline 3. & Niam 30\% & 1,3 & 1,1 & 0,9 & 1 & 1,075 \\
\hline
\end{tabular}

Berdasarkan pengamatan laboratorium dengan pengukuran sebanyak 4 kali ulangan dari tiap diameter zona hambat didapatkan data seperti pada Tabel 6. Minyak atsiri nilam konsentrasi 10\% memiliki kemampuan penghambatan rata-rata sebesar 0,1775 mikrometer. Minyak atsiri nilam konsentrasi 20\% memiliki kemampuan penghambatan rata-rata sebesar 0,17 mikrometer. Sedangkan minyak nilam dengan konsentrasi 30\% memiliki penghambatan ratarata sebesar 1,075 mikrometer yang menunjukkan bahwa nilam merupakan minyak atsiri yang paling efektif 
untuk menghambat bakteri. Hasil ini hampir sama dengan penghambatan yang dihasilkan oleh chloramfenikol yang menghambat rata-rata 1,0075 mikrometer terhadap bakteri. Urutan potensi minyak nilam yang pertama adalah konsentrasi 30\%, 10\%, dan 20\%.

\section{Hasil Pengujian Penghambatan Bakteri dengan Minyak Atsiri Daun Cengkeh}

Hasil pengujian efektifitas minyak atsiri cengkeh dengan berbagai variasi konsentrasi menggunakan metode difusi agar, terhadap bakteri yang ditemukan di Candi Borobudur, disajikan pada Tabel 7 di bawah ini:

\section{Tabel 7. Hasil Uji Penghambatan Bakteri dengan Minyak Daun Cengkeh}

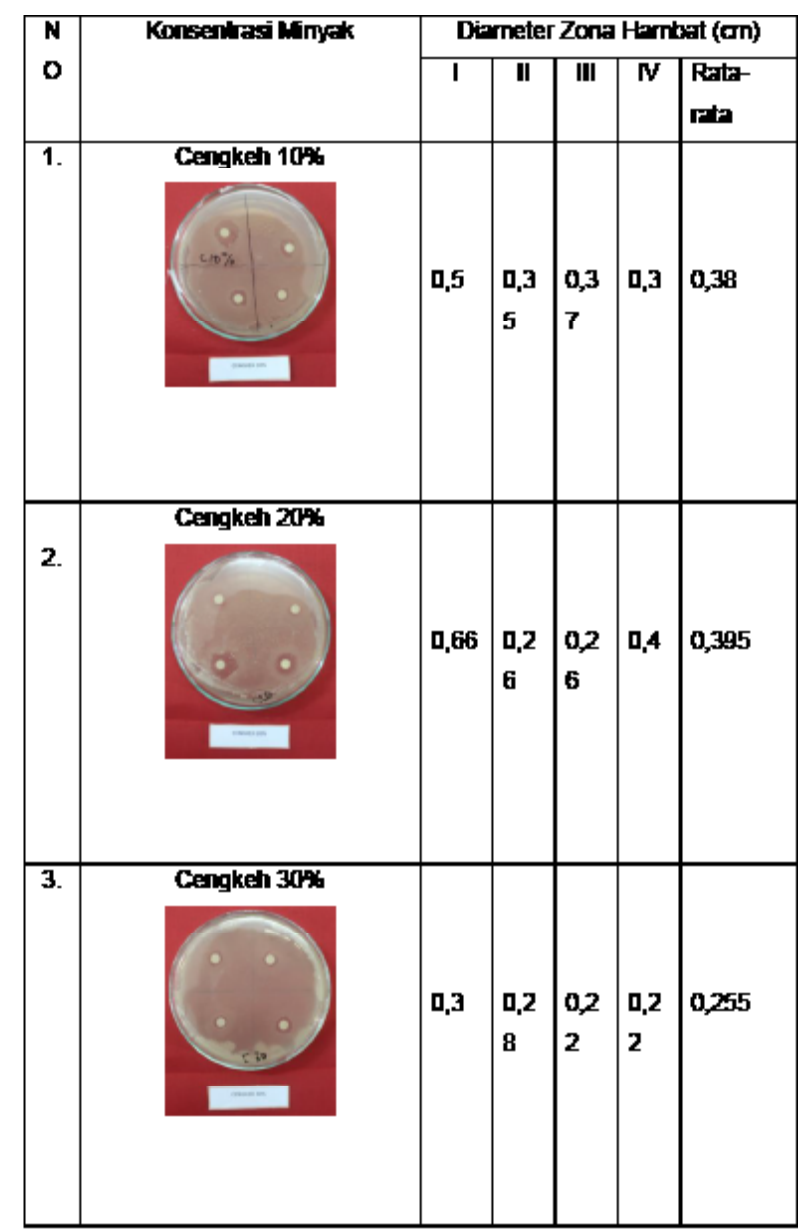

Sedangkan potensi minyak atsiri cengkeh dalam menghambat pertumbuhan bakteri diantaranya adalah konsentrasi cengkeh $10 \%$ dan 20\% memiliki ratarata penghambatan yang lebih baik yaitu rata-rata 0,38 mikrometer dan 0,395 mikrometer dibandingkan dengan pemberian cengkeh konsentrasi 30\% yang menghambat rata-rata 0,255 mikrometer. Sehingga dapat diurutkan potensi minyak atsiri yang efektif dalam mengambat pertumbuhan bakteri candi diantaranya adalah nilam, cengkeh, kemudian temulawak. Selain itu kontrol yang diujikan yaitu akuades, chloramfenikol, dan alkohol 96\% berhasil diaplikasikan sebagai uji positif dan negatif

Berdasarkan hasil pengujian yang telah dilakukan, dibandingkan dengan teori yang ada, penghambatan pertumbuhan bakteri oleh minyak atsiri merupakan salah satu alternatif pemanfaatan bahan alam yang tidak berbahaya untuk diaplikasikan bagi manusia sendiri dibandingkan dengan zat kimia berbahaya sebagai antibakteri. Proses penghambatan bakteri oleh minyak atsiri terjadi dikarenakan kemampuannya untuk berikatan dengan protein ekstra seluler dan dinding sel bakteri. Semakin bersifat lipofilik, maka semakin dapat melakukan disrupsi terhadap membran sel bakteri. Mekanisme penghambatannya diduga melalui perusakan lipid bilayer membran sel akibat gugus hidrofobik yang dimilikinya. (Gunawan, 2010: 106-107). Sedangkan mekanisme kerja minyak atsiri dalam membunuh bakteri adalah dengan cara mengubah permeabilitas membran sel, menghilangkan ion-ion dalam sel, menghalangi protonpump, dan menurunkan produksi adenosin trifosfat (ATP). Minyak atsiri bersifat lipofilik yang dapat melewati dinding bakteri karena dinding bakteri terdiri atas polisakarida, asam lemak, dan fosfolipid. Hal ini dapat mengakibatkan kerusakan dinding sel sehingga dapat membunuh bakteri. Mekanisme kerja minyak atsiri adalah dengan menghambat stabilitas membran sel bakteri dan menyebabkan material sitoplasma menghilang (Diastri, 2015: 12).

Kandungan yang ada pada minyak atsiri nilam, temulawak, dan cengkeh sebagian besar memiliki kandungan unsur yang hampir sama yang berpotensi sebagai antibakteri. Berdasarkan pendapat dari Gunawan (2010) mengatakan bahwa sebagian besar komponen penyusun minyak atsiri adalah senyawa golongan fenil propana. Senyawa ini mengandung cincin fenil C6 dengan rantai samping berupa propana C3. Sebagai contoh senyawa golongan fenil ini adalah sinamilaldehida, anetol, eugenol, feniletil, anisaldehida, dan metil salisilat. Berdasarkan uji kandungan unsur pada minyak atsiri dihasilkan komponen utama senyawa minyak atsiri temulawak adalah 
Longipinene 27,15\% area, $\alpha$-Curcumene 20,55\% area, Phenol 13.37\% area, dan Camphor 9,79\% area (Sri Wahyuni dkk, 2015: 17-18). Komponen senyawa utama minyak atsiri nilam adalah patchouli alkohol 24,62\% area, $\Delta$-Guaiene $17,07 \%$ area, $\alpha-$ Guaiene $13,62 \%$ area, $\alpha$-Patchoulene 8,76\% area. Senyawa Patchouli alkohol merupakan komponen utama minyak ilam bersama dengan $\alpha$-Patchoulene (Sonwa dalam Sri Wahyuni, 2015: 15-16). Sedangkan menurut teori, terpena lain yang berperan penting sebagai penyusun minyak atsiri adalah seskuiterpena dan diterpena. Sebagai contoh adalah kadinena (bisiklik seskuiterpena), B-kariofilena (bisiklik seskuiterpena), dan asam abietat (trisiklik seskuiterpena) (Gunawan, 2010: 106-107).

Selain itu menurut Putra dalam (Diastri, 2015: 11-12) sifat daya hambat senyawa fenol terhadap mikroba disebabkan karena gugus hidroksil yang dimilikinya dapat berinteraksi dengan protein membran sel mikroba melalui ikatan hidrogen sehingga protein tersebut kehilangan fungsinya. Gugus hidroksi dapat menjadi donor hidrogen yang sangat baik untuk membentuk ikatan hidrogen dengan gugus karbonil pada protein. Protein dan fosfolipid merupakan senyawa penting yang menyusun membran sel mikroba, yang mana protein di sini berfungsi sebagai pengatur keluar-masuknya material dari dan ke dalam sel.

Oleh karena itu, kandungan yang dimiliki oleh ketiga jenis minyak atsiri yaitu nilam, cengkeh, dan temulawak terbukti berpotensi sebagai antibakteri. Karena memilik beberapa kandungan utama seperti fenol yang dapat memberikan efek sebagai antibakteri pada bakteri uji hasil isolate dari Candi Borobudur.

Hasil Pengujian Penghambatan Bakteri dengan Kontrol Positif dan Negatif

Berdasarkan hasil pengujian yang telah dilakukan, dibandingkan dengan teori yang ada, penghambatan pertumbuhan bakteri oleh minyak atsiri merupakan salah satu alternatif pemanfaatan bahan alam yang tidak berbahaya untuk diaplikasikan bagi manusia sendiri dibandingkan dengan zat kimia berbahaya sebagai antibakteri. Proses penghambatan bakteri oleh minyak atsiri terjadi dikarenakan kemampuannya untuk berikatan dengan protein ekstraseluler dan dinding sel bakteri. Semakin bersifat lipofilik, maka semakin dapat melakukan disrupsi terhadap membran sel bakteri.
Mekanisme penghambatannya diduga melalui perusakan lipid bilayer membran sel akibat gugus hidrofobik yang dimilikinya. (Gunawan, 2010: 106-107). Sedangkan mekanisme kerja minyak atsiri dalam membunuh bakteri adalah dengan cara mengubah permeabilitas membran sel, menghilangkan ion-ion dalam sel, menghalangi proton-pump, dan menurunkan produksi adenosin trifosfat (ATP). Minyak atsiri bersifat lipofilik yang dapat melewati dinding bakteri karena dinding bakteri terdiri atas polisakarida, asam lemak, dan fosfolipid. Hal ini dapat mengakibatkan kerusakan dinding sel sehingga dapat membunuh bakteri. Mekanisme kerja minyak atsiri adalah dengan menghambat stabilitas membran sel bakteri dan menyebabkan material sitoplasma menghilang (Diastri, 2015: 12).

Kandungan yang ada pada minyak atsiri nilam, temulawak, dan cengkeh sebagian besar memiliki kandungan unsur yang hampir sama yang berpotensi sebagai antibakteri. Senyawa ini mengandung cincin fenil C6 dengan rantai samping berupa propana C3. Sebagai contoh senyawa golongan fenil ini adalah sinamilaldehida, anetol, eugenol, feniletil, anisaldehida, dan metil salisilat. Berdasarkan uji kandungan unsur pada minyak atsiri dihasilkan komponen utama senyawa minyak atsiri temulawak adalah Longipinene 27,15\% area, $\alpha$-Curcumene 20,55\% area, Phenol 13.37\% area, dan Camphor 9,79\% area (Sri Wahyuni, 2015: 17-18). Dan komponen senyawa utama minyak atsiri nilam adalah patchouli alkohol 24,62\% area, $\Delta$-Guaiene17,07\% area, $\alpha$-Guaiene 13,62\% area, $\alpha$-Patchoulene 8,76\% area. Senyawa Patchouli alkohol merupakan komponen utama minyak ilam bersama dengan $\alpha$-Patchoulene (Sonwa dalam Sri Wahyuni, 2015: 15-16).

Selain itu menurut Putra dalam (Diastri, 2015: 11-12) sifat daya hambat senyawa fenol terhadap mikroba disebabkan karena gugus hidroksil yang dimilikinya dapat berinteraksi dengan protein membran sel mikroba melalui ikatan hidrogen sehingga protein tersebut kehilangan fungsinya. Gugus hidroksil dapat menjadi donor hidrogen yang sangat baik untuk membentuk ikatan hidrogen dengan gugus karbonil pada protein Protein dan fosfolipid merupakan senyawa penting yang menyusun membran sel mikroba, yang mana protein di sini berfungsi sebagai pengatur keluar-masuknya material dari dan ke dalam sel. 
Oleh karena itu, kandungan yang dimiliki oleh ketiga jenis minyak atsiri yaitu nilam, cengkeh, dan temulawak terbukti berpotensi sebagai antibakteri. Karena memilik beberapa kandungan utama seperti fenol yang dapat memberikan efek sebagai antibakteri pada bakteri uji hasil isolate dari Candi Borobudur.

\section{Simpulan}

Berdasarkan hasil dan pembahasan maka dapat disimpulkan bahwa hasil pengujian penghambatan bakteri dengan minyak atsiri yang paling berpotensi menghambat adalah minyak nilam dengan konsentrasi 30\% dengan rata-rata penghambatan $1,075 \mathrm{~cm}$. Sedangkan urutan minyak atsiri yang berpotensi dalam penghambatan pertumbuhan bakteri Candi Borobudur adalah minyak atsiri nilam, cengkeh, kemudian temulawak.

\section{Saran}

Saran yang dapat dilakukan selanjutnya adalah:

1. Perlu dilakukan penelitian mengenai identifikasi bakteri yang lebih lengkap dari isolat yang didapatkan di Candi Borobudur.

2. Perlu dilakukan pengujian menggunakan jenis minyak atsiri yang lain untuk mengetahui potensi yang lebih baik sebagai antibakteri

\section{DAFTAR PUSTAKA}

AATCC Technical Manual. (2004). AATCC Test Method 100-1999, Antibacterial Finishes on Textile Materials,

AATCC Technical Manual. (2004). AATCC Test Method 147-1998, Antibacterial Activity Assessment of Textile Materials.

Arrachman, Khairunnisa. (2016). Mikrobiologi Pewarnaan. Semarang: Universitas Muhacmadiyah Semarang.

Chaerun, S.K. (2010). Presentasi Kuliah Biomineralogi. Bandung: Institut Teknologi Bandung.

Danni, G.H. (2011). Proses Pembentukan Biopatina Pada Batuan.Bandung: Institut Teknologi Bandung.

Daud Aris Tanudirjo. (2007). Borobudur yang Inspirational. Jurnal. Volume 1, Nomor 1. Hlm.: $\quad 1-4$.

Diastri, N.S.D. (2015). Aktivitas Antibakteri Minyak Atsiri Batang Sereh (Cymbopogon Citratus) Terhadap Propioni bacterium Acnes Secara In Vitro. Skripsi. Jember:UNJ.

Golan, Oded. (2011). Organic Chemistry, 5 Eth Prinsip dan Mekanisme Biomineralisasi The Authenticity of the James Ossuary and the Jehoash Tablet Inscriptions - Sucmary of Expert Trial Witnesses . Rangkuman Testimoni, Israel Antiquities Authority: Tel Aviv.

Gunawan Didik, Sri Mulyani. (2010). Ilmu Obat Alam (Farmakognosi) jilid I. Jakarta: Penebar Swadaya. Hal 106-107.

Jurnal Konservasi Cagar Budaya Borobudur. Jurnal. Volume 8, Nomor 2, Desember 2014, Hal 410. Koul, O., S. Walia, and G. S. Dhaliwal. (2008). Essential oils as green pesticides: Potential and constrains. Biopesticides. Int. 4 (1): 63-84.

umbein, Wolfgang E. (1997). Cultural Heritage - a Geomicrobiologist's Perspective. Biotechnologies in Cultural Heritage Protection and Conservation: Biodeterioration and its control Patina. 
Madigan, Michael T; Martinko, John M; Dunlap, Paul V; dan Clark, David P. (2009). Brock: Biology of Microorganism 12th editon. Pearson Benyamin Cucmings: San Francissco.

Pratiwi, Arini Eka. (2015). Isolasi Seleksi dan Uji Aktivitas Antibakteri Mikroba Endofit dari Daun Tanaman Garcinia benthami Piere Terhadap S. aureus, B. subtilis, E. coli, S. dysenteriae, dan S. typhimurium. Skripsi. Jakarta: UIN.

Pratiwi, Sylvia T. (2008). Mikrobiologi Farmasi. Gelora Aksara Pratama. Jakarta: P e n e r b i t Erlangga.

Riyanto. (2014). Minyak Atsiri sebagai Bahan Aktif Konservasi Benda Cagar B u d a y a . Journal. Volume 1, Nomor 1, Hal 4-10.

Sastrohamidjojo, H. 2004. Kimia Minyak Atsiri. FMIPA Universitas Gadjah Mada. Yogyakarta.

Sudaryani, T dan Sugiharti, E. (1992). Budidaya dan Penyulingan Nilam. Jakarta: Penebar Swadaya.

Sri Wahyuni, dkk. (2015). Minyak Atsiri untuk Cagar Budaya Berbahan Batu. J o u r n a 1 . Volume 1, Nomor 1, Hal 15-18.

Sri Wahyuni, dkk. (2016). Minyak Atsiri untuk Cagar Budaya Berbahan Batu. J o u r n a 1 . Volume 2, Nomor 2, Hal 17.

Tatang Wahyudi dkk. (2011). Sintesis Nano Partikel Perak dan Uji Aktivitasnya Terhadap Bakteri E. coli dan S. aureus. Journal. Volume 1, Nomor 1, Hal 56.

Undri Rastuti dkk. (2013). Aktivitas Antibakteri Minyak Atsiri Daun Pala Dari Banyumas Terhadap Staphylococcus Aureus dan Escherichia Coli Serta Identifikasi Senyawa. Skripsi. UNSOED: FMIPA.

Wasitaningrum, Ika Dyah Ayu. (2009). Uji Resistensi Bakteri Staphylococcus aureus dan Escherichia coli dari Isolat Susu Sapi Segar Terhadap Beberapa Antibiotik. Skripsi. Surakarta: UMS.

Winda Diah P, Hari Setyawan, Dian Eka Puspita. (2010). Kearsitekturan Candi Borobudur Seri3.]

\section{Balai Konservasi Borobudur hal 1-2.}

